\title{
Effect of cultivar and harvest year on the composition of yellow lupin seeds
}

\author{
R. Lubowicki, A. Kotlarz ${ }^{1}$ and I. Jaskowska \\ University of Agriculture of Szczecin, \\ Department of Animal Nutrition and Feed Management \\ Doktora Judyma 2, 71-466 Szczecin, Poland
}

\section{ABSTRACT}

The seeds of 6 cultivars of yellow lupin from 7 consecutive harvest years, 1992-1998, were subjected to chemical analysis. The obtained results demonstrate significant differences $(\mathrm{P} \leq 0.01$ or $\mathrm{P} \leq 0.05$ ) between the evaluated cultivars in terms of ether extract, ash and alkaloids. Significant $(\mathrm{P} \leq 0.01$ or $\mathrm{P} \leq 0.05)$ differences were also found among harvest years in crude fibre and pentosan contents. The highest content of crude protein characterized cultivars Amulet $\left(445 \mathrm{~g} \cdot \mathrm{kg}^{-1}\right)$ and Teo $\left(441 \mathrm{~g} \cdot \mathrm{kg}^{-1}\right)$ and, depending on harvest year, seeds from $1994\left(443 \mathrm{~g} \cdot \mathrm{kg}^{-1}\right), 1992\left(440 \mathrm{~g} \cdot \mathrm{kg}^{-1}\right)$ and $1995\left(438 \mathrm{~g} \cdot \mathrm{kg}^{-1}\right)$. Differences in the crude protein content were insignificant.

KEY WORDS: yellow lupin, seeds, cultivar, chemical composition, alkaloids

\section{INTRODUCTION}

Among legumes, yellow lupin seeds have a high protein content and a large share of structural carbohydrates and other antinutrients that limit their use in the feeding of monogastric animals (Saini et al., 1989; Wasilewko et al., 1999). Aside from genetic aspects, climatic factors have a major influence on the accumulation of components in plants. Under draught conditions, crops contain relatively more protein and secondary metabolites - in the case of lupins, alkaloids.

The objective of this study was to determine if the variability of nutrients and alkaloid contents in yellow lupin among cultivars and harvest years is significant.

\section{MATERIAL AND METHODS}

The study was conducted on 6 cultivars of fodder lupin from 7 consecutive harvest years, 1992-1998, with the exception of one cultivar, Manru, which was

\footnotetext{
${ }^{1}$ Corresponding author: e-mail: a.kotlarz@biot.ar.szczecin.pl
} 
harvested in 1992-1995. The tested seeds were provided by the plant breeding stations of the cultivars Amulet, Manru, Radames and Teo in Wiatrowo (Poland), whereas the cultivars Parys and Popiel, in Radzików (Poland). The proximate analysis of the seeds was performed by standard methods (AOAC, 1990), cellulose and lignin were determined according to Jacyno et al. (1983), pentosans by the orcinol method of Mejbaum-Katzenellenbogen (1969), and total alkaloids, according to Skolik and Wiewiórowski (1959). Main effect analysis of variance was used to statistically analyse the data for cultivars and harvest years.

\section{RESULTS}

The data given in Table 1 show that there were significant differences between some cultivars $(\mathrm{P} \leq 0.01$ or $\mathrm{P} \leq 0.05)$ in ether extract, nitrogen-free extractives, crude ash, pentosan and alkaloid contents. Year of harvest had a significant effect on the share of ether extract, crude ash, cellulose and pentosans ( $\mathrm{P} \leq 0.01$ or $\mathrm{P} \leq 0.05)$. Unfavourable essential higher total alkaloid contents characterized the cultivars Popiel and Parys in comparison with Amulet, Manru, and Teo $(\mathrm{P} \leq 0.01)$ and Radames $(\mathrm{P} \leq 0.05)$, and $\mathrm{cv}$. Radames in comparison with Amulet and Manru $(\mathrm{P} \leq 0.05)$.

\section{DISCUSSION}

Gdala and Buraczewska (1996) and Wasilewko and Buraczewska (1999) report similar values to ours for crude protein, ether extract, crude ash, crude fibre, lignin, cellulose and hemicellulose contents in the seeds of cultivars Amulet, Popiel, Radames and Manru in the harvest years of 1991-1994. The differences in the alkaloid contents both among cultivars and harvest years are corroborated by the results of the COBORU study (Wiatr, 1995, 1997, 1999). Although the alkaloid content in lupins is genetically determined (Aniszewski, 1993), climatic and soil factors also influence alkaloid biosynthesis directly or indirectly (Waller and Nowacki, 1978). This opinion seems to be supported not only by the large differences in the alkaloid contents among cultivars, but also by the high standard deviations within the same cultivars. 


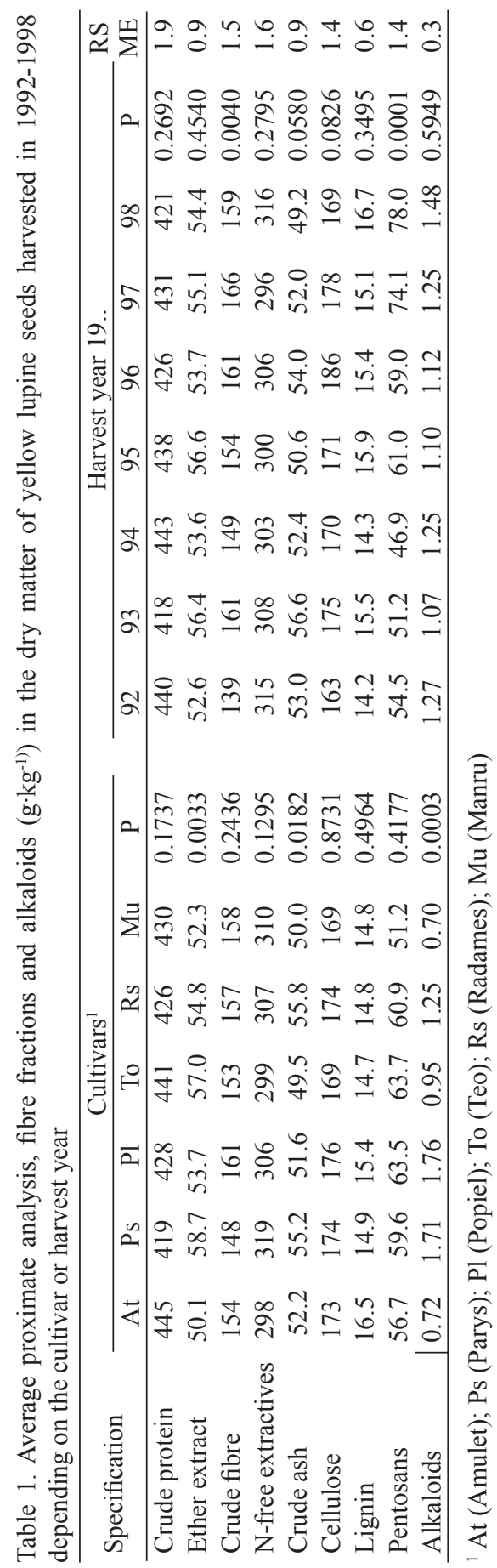




\section{CONCLUSIONS}

The results of this study show significant differences in the proximate composition and alkaloid content of yellow lupin seeds not only among cultivars, but also among harvest years. They also point to the need to chemically analyse every lot of seed, since using the average values given in feeding requirements for animals may be insufficient.

\section{REFERENCES}

AOAC. 1990 Officials Methods of Analysis, Association of Official Analytical Chemist. 15th Edition. Washington, DC

Gdala J., Buraczewska L., 1996. Chemical composition and carbohydrate content of seeds from several lupin species. J. Anim. Feed Sci. 5, 403-416

Jacyno E., Seidler S., Jaskowska I., 1983. Determination of structural components in feeds (in Polish). Zesz. Nauk. AR Szczec. Zoot. 19 (101), 207- 114

Mejbaum-Katzenllenbogen W., 1969. Practical Course in Biochemistry (in Polish). PWN, Warszawa

Saini H.S., 1989. Legume seed oligosaccharides. In: J. Huisman T.F.B. van der Poel, J.E. Liener (Editors). Recent Advances of Research in Antinutritional Factors in Legume Seeds. Pudoc, Wageningen, pp. 329-341

Skolik J., Wiewiórowski M., 1959. Photometric micromethod of estimation of lupin alkaloids (in Polish). Rocz. Chemii 33, 461-466

Wasilewko J., Buraczewska L., 1999. Chemical composition including content of amino acids, minerals and alkaloids in seeds of three lupin species cultivated in Poland. J. Anim. Feed Sci. $8,1-12$

Wiatr K., 1995, 1997, 1999. Lupinus luteus, Lupinus angustifolius, L. albus. Synthesis Results of Variety of Experiments 1994, 1996, 1998 (in Polish). COBORU, Słupia Wielka, 1059, 1115, 1153

\section{STRESZCZENIE}

\section{Ocena wpływu odmiany i roku zbioru na skład chemiczny nasion łubinu żółtego}

Ocenie chemicznej poddano nasiona 6 odmian łubinu żółtego z 7 kolejnych lat zbioru 1992 1998. Wyniki badań wskazują na istotne różnice $(\mathrm{P} \leq 0,01$ lub $\mathrm{P} \leq 0,05)$ pomiędzy ocenianymi odmianami w zawartości ekstraktu eterowego, związków bezazotowych wyciagowych, pentozanów, popiołu oraz alkaloidów. Wykazano również istotne różnice $(\mathrm{P} \leq 0,01$ lub $\mathrm{P} \leq 0,05)$ w zawartości ekstraktu eterowego, celulozy, pentozanów i popiołu surowego pomiędzy latami zbioru. Najwięcej białka zawierały odmiany Amulet $\left(445 \mathrm{~g} \cdot \mathrm{kg}^{-1}\right)$ i Teo $\left(441 \mathrm{~g} \cdot \mathrm{kg}^{-1}\right)$, uwzględniając lata zbioru - nasiona z lat $1994\left(443 \mathrm{~g} \mathrm{~kg}^{-1}\right), 1992\left(440 \mathrm{~g} \cdot \mathrm{kg}^{-1}\right)$ i $1995\left(438 \mathrm{~g} \cdot \mathrm{kg}^{-1}\right)$, lecz różnice były nieistotne. 